\title{
HUBUNGAN INTENSITAS PENYAKIT KARAT DENGAN PRODUKTIVITAS TANAMAN KEDELAI (Glycine max (L.) Merr.) PADA BEBERAPA VARIETAS BERBEDA
}

\author{
Maman, Rochmatino, Juni SAFITRi Muljowati
}

Fakultas Biologi, Universitas Jenderal Soedirman, Jalan dr. Suparno 63 Purwokerto 53122

\section{A B S T R A C T}

The severity of plant disease is closely related to the development of the disease itself, including rusts caused by pathogenic fungi. This research aimed to determine the difference of rusts disease severity and to determine the correlation between rusts disease severity with the productivity of different varieties of soybean. The material used was inoculum of rusts pathogenic fungi, Phakopsora pachyrhizi Syd., and four varieties of soybean, i.e., Slamet, Lokon, Bromo, and Ringgit. This research was a split-plot design experimental with subplot was four different varieties of soybean, and the main plot was the control without the treatment of inoculation (In0). The spores suspension density of inoculum of P. pachyrhizi Syd applied was $104 \mathrm{spores} / \mathrm{ml}$ (In1). The main parameters observed in this study were the height of plants, the number of pods per plant, the number of seeds per plant, the wet and dry weight of the plant, and the total weight of 100 grains seed. The supporting parameters were the disease severity, the soil acidity, the humidity, and the air temperature. The results showed the plant with lowest rusts disease severity was Slamet variety (18,38\%), and the highest was Ringgit variety $(35,92 \%)$. The correlation test showed the increment of rusts disease severity reduced the number of pods and dry weight of the plant in Lokon variety.

KEY WORDS: disease severity, productivity, Phakopsora pachyrhizi Syd.

Penulis korespondensi: MAMAN | email: man_ketos@ymail.com

\section{PENDAHULUAN}

Kedelai merupakan komoditas strategis ketiga setelah padi dan jagung. Produksi kedelai di Indonesia sejak tahun 1995 cenderung mengalami penurunan. Berdasarkan data Badan Pusat Statistik (BPS), pada tahun 2010 produksi kedelai nasional hanya 870.068 ton dibanding produksi tahun 1995 yang mencapai 1.679.092 ton (BPS, 2012). Konsekwensi dari penurunan produksi adalah terjadinya defisit kedelai yang terus bertambah karena konsumsi nasional cenderung meningkat dari tahun ke tahun.

Produksi kedelai dalam negeri yang belum mencukupi kebutuhan nasional membuat pemerintah menetapkan kebijakan import kedelai. Import yang dilakukan setiap tahunnya berkisar dua kali lipat dari produksi nasional, sebagai contoh pada tahun 2010 Indonesia mengimport kedelai sebanyak 1,74 juta ton dimana pada tahun tersebut produksi kedelai nasional hanya 870.068 ton (BPS, 2012). Oleh karena itu, peningkatan produksi kedelai dalam negeri perlu dilakukan untuk mencukupi kebutuhan pangan masyarakat dan import kedelai bisa dikurangi atau bahkan ditiadakan.

Peningkatan produksi kedelai dapat dilakukan dengan berbagai cara. Salah satunya adalah dengan menanam varietas kedelai yang tahan penyakit yang dapat menurunkan produksi kedelai. Salah satu penyakit yang dapat menyebabkan penurunan produksi adalah karat kedelai. Penurunan produksi oleh penyakit ini berkisar antara 40-90\% (Sudjono , 1984). Penggunaan varietas kedelai yang tahan merupakan salah satu cara pengendalian terhadap penyakit karat. Rekomendasi pengembangan varietas unggul kedelai sampai saat ini masih sulit untuk mencapai hasil yang optimal karena areal penanaman kedelai di Indonesia memiliki kondisi lingkungan yang berbeda-beda. Oleh karena itu perlu dikembangkan varietas unggul yang spesifik lokasi. Salah satu cara untuk mendapatkan varietas tahan penyakit adalah dengan mengetahui hubungan antara intensitas penyakit dengan penurunan produktivitas tanaman (Santosa, 2003).

Berdasarkan hal tersebut, tujuan dari penelitian ini adalah untuk mengetahui perbedaan intensitas penyakit karat dan hubungannya dengan produktivitas tanaman kedelai pada beberapa varietas yang berbeda. Berdasarkan informasi ini diharapkan produktivitas tanaman kedelai dapat ditingkatkan melalui pemilihan varietas yang tahan terhadap serangan Phakopsora pachyrhizi Syd.

\section{MET ODE}

Penelitian dilaksanakan di Kebun Percobaan dan Laboratorium Fisiologi Tumbuhan Fakultas Biologi Unsoed dari bulan Juni sampai September 2012. Metode yang digunakan adalah metode eksperimental berupa Rancangan Petak Terbagi (Split-Plot Design) dengan sub plot empat varietas kedelai yang berbeda yaitu Lokon, Slamet, Bromo dan Ringgit sedangkan main plot-nya adalah perlakuan tanpa inokulasi (In0) dan dengan inokulasi suspensi spora P. pachyrhizi Syd. dengan kerapatan $10^{4} \mathrm{spora} / \mathrm{ml}(\operatorname{In} 1)$.

Parameter utama yang diamati dalam penelitian ini yaitu tinggi tanaman, jumlah polong per tanaman, jumlah biji bernas per tanaman, berat basah dan berat kering tanaman serta berat 100 butir biji sedangkan parameter pendukungnya yaitu intensitas penyakit karat (IP), $\mathrm{pH}$ tanah, kelembapan udara dan suhu udara. Data intensitas penyakit karat dan data produktivitas tanaman kedelai dianalisis dengan Uji korelasi (Sudjono, 1984). Data tersebut dianalisis pula dengan Analisis ragam (Anova) pada tingkat kesalahan $5 \%$ dan $1 \%$. Hasil yang menunjukkan perbedaan yang nyata kemudian diuji lanjut dengan uji BNJ pada tingkat kesalahan $5 \%$ dan $1 \%$. 
Daun kedelai yang terinfeksi jamur karat diambil dari pertanaman. Pustul karat pada daun dikerat hingga terlepas dan ditampung dalam gelas beker yang berisi akuades steril. Campuran tersebut disaring menggunakan kain kasa sehingga kotoran terpisah dengan suspensi uredospora karat kedelai, selanjutnya kerapatan uredospora dihitung sampai kerapatannya mencapai $10^{4}$ uredospora/ml dengan menggunakan haemositometer (Karnu'ah, 2010). Inokulasi uredospora P. pachyrhizi Syd. dilakukan pada tanaman yang telah berumur 3 minggu setelah tanam (mst). Inokulasi dilakukan pada pagi hari dan diulang 3 kali dengan interval waktu 4 hari.

Pengamatan intensitas penyakit dilakukan pada tanaman kedelai umur 7 mst (IP7), 8 mst (IP8), 9 mst (IP9) dan 10 mst (IP10). Hal ini dikarenakan pada kisaran umur tersebut, tanaman kedelai memiliki nilai intensitas penyakit tertinggi (Sudjono, 1984). Intensitas penyakit karat dihitung dengan menggunakan rumus yang dijelaskan oleh Djafaruddin (2008), yaitu sebagai berikut:

$$
I P=\frac{\Sigma \text { nivi }}{N Z} \chi 100 \%
$$

Keterangan:

IP = Intensitas penyakit

ni = Jumlah daun pada skala ke-i

vi = Nilai skala ke-i

$\mathrm{N}=$ Jumlah daun yg diamati

$\mathrm{Z}$ = Skala tertinggi dari sampel yang diamati

Skala penilaian yang digunakan adalah berdasarkan pada luasan daun yang menunjukan gejala penyakit karat (Utomo et al., 2005), yaitu seperti dijelaskan pada Table 1.

Tabel 1. Penentuan skala penilaian berdasarkan luasan daun yang menunjukan gejala penyakit karat

\begin{tabular}{cl}
\hline Skala & Jumlah pustul pada daun \\
\hline 0 & Tidak ada pustul karat \\
1 & Terdapat pustul 1-20\% dari luas daun \\
2 & Terdapat pustul $21-40 \%$ dari luas daun \\
3 & Terdapat pustul $41-60 \%$ dari luas daun \\
4 & Terdapat pustul $61-80 \%$ dari luas daun \\
5 & Terdapat pustul $81-100 \%$ dari luas daun \\
\hline
\end{tabular}

Nilai intensitas penyakit dari setiap varietas dapat menjadi kriteria dalam menentukan suatu ketahanan terhadap suatu penyakit. Berikut adalah kriteria ketahanan terhadap penyakit karat menurut Mizzani dan Hinojosa (Cook, 1972),

Tabel 2. Kriteria ketahanan terhadap penyakit karat

\begin{tabular}{ll}
\hline Kriteria & Intensitas penyakit (IP) \\
\hline Imun & $\mathrm{IP}=0 \%$ \\
Tahan & $0 \%<\mathrm{IP} \leq 25 \%$ \\
Agak Tahan & $25 \%<\mathrm{IP} \leq 50 \%$ \\
Agak Rentan & $50 \%<\mathrm{IP} \leq 75 \%$ \\
Rentan & $75 \%<\mathrm{IP} \leq 100 \%$ \\
\hline
\end{tabular}

\section{HASIL DAN PEMBAHASAN}

Kondisi lingkungan dari mulai pengolahan tanah sampai pemanenan relatif stabil yaitu cuaca terik, suhu lingkungan pada pagi hari berkisar $25,9-28,8^{\circ} \mathrm{C}$, siang hari $27,0-30,5^{\circ} \mathrm{C}$ dan pada sore hari berkisar $27,4-31,8^{\circ} \mathrm{C}$, sedangkan kelembapan udara pada pagi hari berkisar 68,3-83,5\%, siang hari 59,6-67,8\% dan pada sore hari berkisar 59,5-68,9\%. Nilai pH tanah diawal penelitian adalah 6,9-7,0 dan pada akhir penelitian menjadi 6,7-6,9. Menurut Nazar et al.
(2008), kondisi lingkungan seperti itu masih memenuhi syarat tumbuh bagi tanaman kedelai yaitu suhu udara berkisar $23-30^{\circ} \mathrm{C}$, kelembapan $60-70 \%$ dan $\mathrm{pH}$ tanah berkisar 5,8-7.

Hasil analisis koefisien korelasi antara intensitas penyakit karat pada 10 mst (IP10) dengan komponen produktivitas tanaman kedelai pada keempat varietas tertera dalam Tabel 3. IP10 ternyata berkorelasi negatif yang nyata terhadap jumlah polong per tanaman dan berat kering tanaman pada varietas Lokon. Hal ini menunjukkan bahwa semakin tinggi intensitas penyakit karat maka jumlah polong per tanaman dan berat kering tanaman pada varietas Lokon akan mengalami penurunan. Hasil penelitian ini sesuai dengan hasil penelitian Masnenah et al. (2004) yang menyatakan bahwa secara umum dengan meningkatnya intensitas penyakit karat maka berat 100 butir biji, jumlah biji bernas per polong, dan jumlah polong per tanaman mengalamai penurunan. Hasil penelitian lain menunjukan bahwa, penyakit karat dapat menurunkan jumlah polong per tanaman, jumlah biji per tanaman, dan berat 100 butir (Asian Vegetable Research and Development Centre, 1986).

Tabel 3. Koefisien korelasi antara intensitas penyakit karat umur 10 mst (IP10) dengan komponen produktivitas pada empat varietas kedelai yang berbeda

\begin{tabular}{lcccccc}
\hline Varietas & T6 & JP & BS & BB & BK & B100 \\
\hline Slamet & 0,506 & $-0,208$ & $-0,461$ & $-0,239$ & 0,622 & 0,745 \\
\hline Lokon & $-0,509$ & $-0,867^{*}$ & $-0,448$ & $-0,670$ & $-0,821^{*}$ & $-0,678$ \\
\hline Bromo & $-0,808$ & 0,064 & $-0,076$ & $-0,386$ & $-0,620$ & $-0,088$ \\
\hline Ringgit & 0,762 & $-0,352$ & 0,369 & $-0,517$ & 0,250 & $-0,522$ \\
\hline Keterangan: ${ }^{*}=$ Korelasi berbeda nyata pada & tingkat kesalahan \\
5\%, T6 = Tinggi tanaman umur 6 mst, JP = Jumlah polong per \\
tanaman, BS = Jumlah biji bernas per tanaman, BB = Berat basah \\
tanaman, BK = Berat kering tanaman, B100 = Berat 100 butir biji
\end{tabular}

Tidak terdapatnya hubungan yang nyata antara IP10 dengan beberapa komponen produktivitas lainnya tampaknya dipengaruhi oleh nilai IP10 pada setiap varietas yang nilainya tidak begitu besar dan tidak saling berbeda jauh antar varietas. Nilai rata-rata IP10 dari setiap varietas ditunjukan pada Tabel 4. Nilai rata-rata tertinggi terdapat pada varietas Ringgit sebesar 35,92\% diikuti oleh varietas Lokon, Bromo dan Slamet dengan nilai masing-masing IP10 adalah $33,47 \%, 24,63 \%$ dan 18,38\%. Kisaran nilai IP10 yang tidak terlalu besar (kurang dari 40\%) diduga karena serangan potogen karat yang kurang tinggi saat penelitian dilakukan yaitu diakhir bulan Juni sampai bulan September 2012. Pada bulan tersebut keadaan musim saat penelitian adalah musim kemarau. Menurut Sudjono (1984), serangan potogen karat berkurang pada musim kemarau atau sekitar awal bulan Mei sampai bulan September

Tabel 4. Rerata nilai IP10 pada setiap varietas kedelai (\%)

\begin{tabular}{lrrr}
\hline Varietas & $\begin{array}{r}\text { Tanpa inokulasi } \\
\text { (In0) }\end{array}$ & $\begin{array}{r}\text { Inokulasi } \\
\text { (In1) }\end{array}$ & $\begin{array}{r}\text { Rata-rata } \\
\text { IP10 }\end{array}$ \\
\hline Slamet & 17,77 & 18,99 & 18,38 \\
Lokon & 35,56 & 31,39 & 33,47 \\
Bromo & 23,91 & 25,35 & 24,63 \\
Ringgit & 35,59 & 36,25 & 35,92 \\
\hline
\end{tabular}


Hasil analisis ragam terhadap intensitas penyakit karat pada tanaman kedelai umur 7, 8, 9 dan 10 minggu setelah tanam (IP7, IP8, IP9 dan IP10) pada empat varietas yang berbeda tertera dalam Tabel 5. Berdasarkan analisis ragam diketahui bahwa interaksi antara inokulasi (In0/In1) dan varietas kedelai yang digunakan berpengaruh nyata terhadap nilai intensitas penyakit karat kedelai umur 7 mst, 8 mst, 9 mst dan 10 mst.

Perlakuan inokulasi atau main plot (In0/In1) secara mandiri tidak berpengaruh nyata terhadap nilai intensitas penyakit karat kedelaidisetiap umur tanaman sedangkan perbedaan macam varietas yang digunakan secara nyata mempengaruhi nilai intensitas penyakit karat. Hasil yang tidak nyata pada perlakuan inokulasi terjadi karena penempatan antara perlakuan tanpa inokulasi (In0) dan dengan inokulasi uredospora $P$. pachyrhizi Syd. ditempatkan pada areal yang sama dan berdekatan sehingga dimungkinkan tanaman yang tidak diinokulasi pun akan terinfeksi uredospora $P$. pachyrhizi Syd. yang terbawa oleh angin dari tanaman yang diinokulasi. Menurut Ramlan dan Nurjanani (2011), penyebaran uredospora $P$. pachyrhizi Syd. dapat terjadi oleh hembusan angin atau melalui air ketika turun hujan.

Perlakuan inokulasi (main plot) yang tidak berpengaruh nyata terhadap semua nilai intensitas penyakit diduga pula karena suhu dan kelembapan yang tidak sesuai untuk perkecambahan uredospora. Suhu saat penelitian berkisar $25-31^{\circ} \mathrm{C}$ sedangkan uredospora dapat berkecambah dengan baik pada suhu $18-21^{\circ} \mathrm{C}$ dan kelembapan yang tinggi (Sudjono,
1984). Pada daerah yang memiliki kelembapan udara yang tinggi, penyakit ini dapat menimbulkan kerusakan pada seluruh areal pertanaman kedelai (Sinclair dan Shurtleff, 1975).

Hasil uji BNJ pengaruh perbedaan varietas terhadap IP7, IP8, IP9 dan IP10 disajikan pada Tabel 6. Hasil uji BNJ menunjukkan bahwa pada setiap waktu pengamatan, nilai IP terendah didapat pada kedelai varietas Slamet. Varietas Bromo memiliki rataan terendah kedua sedangkan varietas Lokon memiliki rataan terendah berikutnya. Nilai IP tertinggi terdapat pada varietas Ringgit. Perbedaan intensitas penyakit ini diduga disebabkan oleh tetua galur kedelai yang diuji berbeda. Dengan kata lain, gen pengendali ketahanan yang dimiliki oleh masingmasing galur kemungkinan berbeda. Menurut Crowder (1997), karakter ketahanan tanaman dikendalikan oleh satu atau beberapa gen.

Rataan intensitas penyakit dari setiap varietas yang diuji dapat dijadikan dasar dalam menggolongkan tingkat ketahanan suatu varietas. Berdasarkan penggolongan dengan ketentuan Mizzani dan Hinojosa (Cook, 1972) seperti Tabel 2, maka ketahanan dari setiap varietas yang diuji dapat disajikan seperti Tabel 7. Berdasarkan tabel tersebut, varietas Slamet dan Bromo termasuk kedalam varietas yang tahan sedangkan varietas Lokon dan Ringgit termasuk varietas yang agak tahan. Hal ini sesuai dengan pernyataan Suhartina (2005), dimana varietas Slamet dan Bromo digolongkan kedalam varietas yang tahan terhadap patogen $P$. pachyrhizi Syd.

Tabel 5. Analisis ragam intensitas penyakit karat umur 7 mst, 8 mst, 9 mst dan 10 mst (IP7, IP8, IP9 dan IP10)

\begin{tabular}{lcccc}
\hline \multirow{2}{*}{ Sumber keragaman } & Db & \multicolumn{3}{c}{ Signifikansi } \\
\cline { 3 - 5 } & & IP7 & IP8 & IP9 \\
\hline Koreksi model & 7 & 0,000 & 0,000 & 0,000 \\
Intercept & 1 & 0,000 & 0,000 & 0,000 \\
MP & 1 & 1,000 & 1,000 & 0,614 \\
SP & 3 & $0,000^{*}$ & $0,000^{*}$ & 0,000 \\
MP ${ }^{*}$ SP & 3 & $0,021^{*}$ & $0,039 *$ & 0,862 \\
Galat & 16 & & & $0,000^{*}$ \\
$0,013^{*}$ &
\end{tabular}

Galat

Keterangan: * = berbeda nyata pada tingkat kesalahan $5 \%$

Tabel 6. Uji BNJ pengaruh varietas kedelai terhadap IP7, IP8, IP9 dan IP10

\begin{tabular}{|c|c|c|c|c|}
\hline \multirow[b]{2}{*}{ Varietas } & \multicolumn{4}{|c|}{ Ratan intenitas Penyakit } \\
\hline & $\begin{array}{l}\text { IP7 } \\
(\sqrt{ }(x+0,5))\end{array}$ & $\begin{array}{l}\text { IP8 } \\
(\sqrt{(x+0,5))}\end{array}$ & $\begin{array}{l}\text { IP9 } \\
(\sqrt{(x+0,5))}\end{array}$ & $\begin{array}{l}\text { IP10 } \\
(\operatorname{Arc} \sin \sqrt{x})\end{array}$ \\
\hline Slamet & $0,7467 \mathrm{a}$ & $0,7717 \mathrm{a}$ & $0,7867 a$ & $25,3817 \mathrm{a}$ \\
\hline Bromo & $0,7933^{b}$ & $0,8200^{b}$ & $0,8333^{b}$ & $29,7433^{b}$ \\
\hline Lokon & $0,8050^{\mathrm{b}}$ & $0,8250^{\mathrm{bc}}$ & $0,8450^{\mathrm{bc}}$ & $35,3417 c$ \\
\hline Ringgit & $0,8250^{c}$ & $0,8433^{c}$ & $0,8567 \mathrm{c}$ & $36,8150^{c}$ \\
\hline
\end{tabular}

Keterangan: angka-angka yang diikuti huruf yang sama pada kolom yang sama tidak berbeda nyata pada BNJ 5\%

Tabel 7. Tingkat ketahanan varietas kedelai terhadap penyakit karat

\begin{tabular}{|c|c|c|c|c|}
\hline \multirow{2}{*}{ Varietas } & \multicolumn{2}{|c|}{ Nilai IP10 (\%) } & \multirow{2}{*}{ Rataan (\%) } & \multirow{2}{*}{ Tingkat ketahanan } \\
\hline & In0 & In1 & & \\
\hline Slamet & 17,77 & 18,99 & 18,38 & Tahan \\
\hline Lokon & 35,56 & 31,39 & 33,48 & Agak tahan \\
\hline Bromo & 23,91 & 25,35 & 24,63 & Tahan \\
\hline Ringgit & 35,59 & 36,25 & 35,92 & Agak tahan \\
\hline
\end{tabular}


Tabel 8. Analisis ragam pengukuran tinggi tanaman 3 mst, 4 mst, 5 mst dan 6 mst (T3, T4, T5 dan T6)

\begin{tabular}{lccccc}
\hline \multirow{2}{*}{ Sumber keragaman } & \multirow{2}{*}{$\mathbf{d b}$} & $\mathbf{3}$ Signifikansi \\
\cline { 3 - 6 } & & $\mathbf{T 3}$ & $\mathbf{T 4}$ & $\mathbf{T 5}$ & T6 \\
\hline Koreksi model & 7 & 0,749 & 0,347 & 0,249 & 0,229 \\
Intercept & 1 & 0,000 & 0,000 & 0,000 & 0,000 \\
MP & 1 & 0,227 & 0,205 & 0,375 & 0,977 \\
SP & 3 & 0,495 & 0,259 & 0,125 & 0,078 \\
MP ${ }^{*}$ SP & 3 & 0,991 & 0,516 & 0,458 & 0,501 \\
Eror & 16 & & & \\
Koreksi total & 23 & &
\end{tabular}

Tabel 9. Analisis ragam pengamatan jumlah polong per tanaman (JP), jumlah biji bernas per tanaman (BS), berat basah tanaman (BB), berat kering tanaman (BK) dan berat 100 butir biji (B100)

\begin{tabular}{|c|c|c|c|c|c|c|}
\hline \multirow{2}{*}{ Sumber keragaman } & \multirow{2}{*}{ db } & \multicolumn{5}{|c|}{ Signifikansi } \\
\hline & & $\mathbf{J P}$ & BS & BB & BK & B100 \\
\hline Koreksi model & 7 & 0,001 & 0,130 & 0,233 & 0,484 & 0,000 \\
\hline Intercept & 1 & 0,000 & 0,000 & 0,000 & 0,000 & 0,000 \\
\hline $\mathrm{MP}$ & 1 & 0,122 & 0,225 & 0,469 & 0,053 & 0,300 \\
\hline SP & 3 & $0,000^{*}$ & 0,066 & 0,086 & 0,703 & $0,000 *$ \\
\hline $\mathrm{MP} * \mathrm{SP}$ & 3 & 0,601 & 0,395 & 0,557 & 0,807 & 0,100 \\
\hline Galat & 16 & & & & & \\
\hline Koreksi total & 23 & & & & & \\
\hline
\end{tabular}

Tabel 10. Uji BNJ pengaruh varietas terhadap komponen produktivitas tanaman kedelai

\begin{tabular}{llllll}
\hline \multirow{2}{*}{ Varietas } & \multicolumn{5}{c}{ Rataan komponen produksi } \\
\cline { 2 - 6 } & JP & BS & BB & BK & B100 \\
\hline Slamet & $25,5000^{\mathrm{a}}$ & $60,000^{\mathrm{a}}$ & $33,3483^{\mathrm{a}}$ & $17,2917^{\mathrm{a}}$ & $13,0817^{\mathrm{a}}$ \\
Ringgit & $28,5000^{\mathrm{ab}}$ & $57,833^{\mathrm{a}}$ & $30,5933^{\mathrm{a}}$ & $16,6033^{\mathrm{a}}$ & $8,7500^{\mathrm{b}}$ \\
Lokon & $30,6667^{\mathrm{bc}}$ & $58,000^{\mathrm{a}}$ & $30,0967^{\mathrm{a}}$ & $16,0550^{\mathrm{a}}$ & $8,8000^{\mathrm{b}}$ \\
Bromo & $34,5000^{\mathrm{c}}$ & $62,167 \mathrm{a}$ & $30,9167^{\mathrm{a}}$ & $17,2317^{\mathrm{a}}$ & $8,8300^{\mathrm{b}}$ \\
\hline
\end{tabular}

Keterangan: angka-angka yang diikuti huruf yang sama pada kolom yang sama tidak berbeda nyata pada BNJ 5\%

Namun untuk varietas Ringgit termasuk varietas yang sangat rentan dan varietas Lokon termasuk ke dalam varietas yang agak rentan. Perubahan tingkat ketahanan suatu varietas yang diuji terhadap penyakit karat diduga disebabkan oleh perbedaan waktu dan lokasi penelitian. Menurut Sudjono (1984), intensitas penyakit karat kedelai akan lebih tinggi pada musim hujan dibandingkan pada musim kemarau.

Pengamatan tinggi tanaman diakhiri pada waktu pengamatan mencapai $6 \mathrm{mst}$, hal ini dikarenakan pertumbuhan generatifnya telah dimulai. Tanda bahwa tanaman kedelai telah memasuki fase generatif adalah munculnya bunga. Perbedaan tinggi tanaman kemudian dianalisis dengan analisis ragam yang hasilnya disajikan pada Tabel 8. Perlakuan inokulasi (In0/In1) dan perlakuan varietas dan interaksinya di setiap umur tanaman diketahui tidak berpengaruh nyata terhadap tinggi tanaman. Hal ini diduga karena pada fase vegetatif intensitas penyakit masih sangat rendah sehingga tidak banyak memberikan pengaruh terhadap tinggi tanaman.

Berdasarkan analisis ragam pada Tabel 9. diketahui bahwa perlakuan inokulasi tidak berpengaruh nyata terhadap semua komponen produktivitas yang diamati sedangkan perlakuan pengaruh varietas terhadap komponen produksi berpengaruh nyata terhadap jumlah polong dan berat 100 butir biji. Interaksi antara perlakuan inokulasi dan macam varietas untuk semua komponen produksi pun tidak ada yang berpengaruh nyata. Tidak adanya interaksi ini diduga karena nilai intensitas penyakit yang rendah dan tidak berbeda nyata antara tanaman yang diinokulasi (In1) dan tanaman tanpa inokulasi uredospora P. pachyrhizi Syd. (In0).

Interaksi antara inang dan patogen bergantung pada keadaan lingkungan, baik biotik maupun abiotik. Selain itu manusia dapat mempengaruhi inang, potogen dan lingkungan. Manusia berperan dalam menentukan perkembangan dan pengendalian epidemi suatu penyakit, oleh karena penyakit itu sendiri merupakan hasil interaksi antar ketiga faktor tersebut (Sudjono, 1984).

Perlakuan varietas kedelai terhadap jumlah polong per tanaman, jumlah biji bernas per tanaman, berat basah tanaman, berat kering tanaman dan berat 100 butir biji diuji lanjut dengan uji BNJ seperti yang tertera pada Tabel 10. Hasil uji BNJ perlakuan varietas kedelai terhadap jumlah polong menunjukkan bahwa rataan jumlah polong terendah dimilki oleh varietas Slamet dan rataan tertinggi terdapat pada varietas Bromo. Pada berat 100 butir biji, varietas Slamet memiliki rataan tertinggi sedangkan rataan terendah terdapat pada varietas Ringgit.

Varietas Slamet memiliki jumlah polong per tanaman yang paling sedikit walaupun varietas tersebut merupakan varietas yang memiliki nilai 
intensitas penyakit terendah dibandingkan varietas lainnya. Hal ini diduga karena selain dipengaruhi oleh penyakit karat kedelai, sedikit atau banyaknya jumlah polong dtentukan pula oleh faktor genetik yang sifatnya turun-temurun. Faktor lain yang menentukan jumlah polong per tanaman adalah banyaknya buku-buku baik cabang maupun batang. Polong yang banyak mengindikasikan tingginya hasil kedelai (Suharno, 2006).

Varietas Ringgit memiliki rataan berat 100 butir biji terendah. Hal ini sejalan dengan intensitas penyakit pada varietas ringgit yang merupakan intensitas penyakit tertinggi dibandingkan ketiga varietas lainnya. Menurut Kumudini et al. (2008), tingginya intensitas penyakit dapat mengakibatkan daun-daun berguguran sebelum waktunya, berkurangnya bagian daun yang sehat karena luka karat dan penurunan kandungan klorofil. Hal ini mengakibatkan menurunnya penyerapan cahaya matahari untuk proses fotosintesis. Berkurangnya penyerapan cahaya mengakibatkan rendahnya efisiensi reaksi fotokimia pada fotosistem II yaitu pada proses fotofosforilasi dan fotolisis air. Terhambatnya proses fotofosforilasi mengakibatkan pembentukan ATP menjadi tidak maksimal sedangkan terhambatnya fotolisis air mengakibatkan pemecahan air menjadi atom hidrogen dan oksigen menjadi tidak maksimal pula. Atom hidrogen digunakan untuk mereduksi NADP menjadi NADPH2. Sedangkan ATP dan $\mathrm{NADPH}_{2}$ sangat diperlukan untuk memfiksasi $\mathrm{CO}_{2}$ pada reaksi gelap atau siklus Calvin yang merupakan tahap lanjutan dari proses fotosintesis. Hal ini mengakibatkan produk dari proses fotosintesis yang berupa molekul gula menjadi sulit terbentuk sedangkan molekul gula tersebut akan digunakan untuk proses respirasi atau menyusun senyawa organik lainnya dalam sel tumbuhan. Menurut Agrios (1988), jika keadaan seperti itu terus berlanjut maka dapat mengakibatkan terhambatnya pertumbuhan dan menurunkan produktivitas tanaman.

Rataan berat 100 butir biji menunjukkan bahwa varietas Slamet memiliki rataan tertinggi dibanding varietas lainnya. Hal ini berhubungan dengan hasil perhitungan intensitas penyakit dimana varietas Slamet merupakan varietas yang memiliki nilai intensitas penyakit terendah. Rendahnya nilai intensitas penyakit pada varietas Slamet menyebabkan proses fotosintesis tidak banyak terpengaruh oleh adanya serangan patogen tersebut sehingga fotosintat tetap dihasilkan dengan baik dan terakumulasi pada organ penyimpanan (biji). Menurut Robinson (1976), tanaman yang mampu menahan serangan suatu jenis patogen sehingga kerusakan yang ditimbulkannya tidak mengakibatkan penurunan hasil adalah tanaman yang mempunyai sifat resistensi yang baik.

\section{K E S I M P U L A N}

Varietas kedelai menunjukkan ketahanan yang berbeda-beda terhadap patogen karat kedelai. Varietas Slamet memiliki intensitas penyakit terendah sedangkan varietas Ringgit memiliki intensitas tertinggi diantara keempat varietas yang diuji. Semakin tinggi intensitas penyakit maka jumlah polong dan berat kering tanaman pada varietas Lokon mengalami penurunan.

\section{AF T AR REFERENSI}

Agrios GN. 1988. Plant Pathology. California: Academic Press, Inc.

Asian Vegetable Research and Development Centre, 1986. Studies on Physiological Reactions of Soybean Cultivar Tolerant and Susceptible to Rust Phakopsora pachyrhizi syd. AVRDC Progress Report for 1986. P.156-160.

Badan Pusat Statistik (BPS). Tabel Luas Panen-ProduktivitasProduksi Tanaman Kedelai Provinsi Indonesia. URL: http://www.bps.go.id/tnmn_pgn. Diakses 16 Januari 2012.

Cook M. 1972. Screening of Peanut for Resistance to Peanut Rust in the Green house and Field. Plant Disease Reporter. 56(5):382-386.

Crowder LV. 1997. Genetika Tumbuhan. Diterjemahkan oleh Lilik Kusdiarti. Gajah Mada University Press. P. 499.

Djafaruddin. 2008. Dasar-Dasar Pengendalian Penyakit Tanaman. Bumi Aksara, Jakarta.

Karnu'ah. 2010. Penjaringan 13 Genotip Kedelai Terhadap Cekaman Penyakit Karat Daun [Skripsi]. Fakultas Pertanian Universitas Jenderal Soedirman, Purwokerto.

Kumudini S, Godoy CV, Board JE, Omielan J, Tollenaar M. 2008. Mechanisms Involved in Soybean Rust-Induced Yield Reduction. M. Crop Science. 48(6):2334-2342.

Masnenah E, Murdaningsih HK, Setiamihardja R, Wenten A Baihaki A. 2004. Korelasi Beberapa Karakter Morfologi dengan Ketahanan Kedelai terhadap Penyakit Karat. Zuriat. 15(1):4046.

Nazar A, Mustikawati DR, Yani A. 2008. Teknologi Budidaya Kedelai. Balai Besar Pengkajian dan Pengembangan Teknologi Pertanian, Lampung.

Ramlan, Nurjanani, 2011. Pengenalan Penyakit Karat Daun (Phakopsora pachyrhizi) dan Pengelolaannya pada Kedelai. Suara Perlindungan Tanaman. 1(4):9-14.

Robinson RA. 1976. Plant Pathosystems. Springer, 184h. Berlin.

Santosa B. 2003. Penyaringan Galur Kedelai terhadap Penyakit Karat Daun Isolat Arjasari di Rumah Kaca. Buletin Plasma Nutfah. 9(1):26-32.

Sinclair JB, Shurtleff MC. 1975. Compendium of Soybean Diseases. The American Phytopathological Society. Inc.

Sudjono MS. 1984. Epidemiologi dan Pengendalian Penyakit Karat Kedelai (Phakopsora pachyrhizi Syd.). Fakultas Pasca Sarjana Institut Pertanian Bogor. Bogor.

Suharno. 2006. Kajian Pertumbuhan dan Produksi pada 8 Varietas Kedelai (Glycine $\max (\mathrm{L})$ Merr.) di Lahan Sawah Tadah Hujan. Jurnal Ilmu-ilmu Pertanian. 2(1):65-72.

Suhartina. 2005. Deskripsi Varietas Unggul Kacang-kacangan dan Umbi-umbian. Balai penelitian Tanaman Kacang-kacangan dan umbi-umbian, Malang.

Utomo SD, Setiowati E, Akin HM. 2005. Ketahanan Terhadap Penyakit Bercak Daun Lambat (Cercosporidium personatum) dan Karakter Agronomi Kacang Tanah Famili F5 Keturunan Persilangan Kelinci x Southern Runner. Jurnal Hama dan Penyakit Tumbuhan Tropika. 5(2):104-112. 